УДК 557.13:582.711.71

\title{
СОДЕРЖАНИЕ ФЛАВОНОИДОВ В НЕКОТОРЫХ ПРЕДСТАВИТЕЛЯХ CEMЕЙСТВА ROSACEAE JUSS. ИЗ ПРИРОДНЫХ ПОПУЛЯЦИЙ ЛЕСОСТЕПНОЙ ЗОНЫ ЗАПАДНОЙ СИБИРИ
}

\author{
(C) Т.М. Шалдаева
}

\author{
Центральный сибирский ботанический сад СО РАН, ул. Золотодолинская, \\ 101, Новосибирск, 630090 (Россия), e-mail: tshaldaeva@ yandex.ru
}

\begin{abstract}
Приводятся экспериментальные данные по содержанию флавоноидов в шести видах семейства Rosaceae. Наибольшее содержание флавоноидов обнаружено в листьях, цветках и корнях манжетки обыкновенной, в листьях и цветках лабазника обыкновенного.

Ключевые слова: Rosaceae, флавоноиды.
\end{abstract}

\section{Введение}

В настоящее время биологически активные вещества растительного происхождения приобретают большое значение, так как обладают меньшим побочным действием, чем синтетические препараты, и сходны по структуре и действию с естественными компонентами организма человека. Среди различных классов природных соединений, обусловливающих их лечебный эффект, значительное место занимают флавоноиды. Они имеют широкий спектр фармакологической активности: обладают Р-витаминной активностью, уменьшают хрупкость кровеносных капилляров, усиливают действие аскорбиновой кислоты, оказывают седативное и антиоксидантное действие, действуют как противовоспалительные, противоязвенные, противолучевые и другие средства $[1,2]$. Удачное сочетание малой токсичности и высокой биологической активности делает их перспективными для профилактики и лечения различных заболеваний, поэтому поиск растений, содержащих значительное количество флавоноидов, - весьма актуальная и важная задача.

Цель настоящей работы - исследование на содержание флавоноидов некоторых представителей сем. Rosaceae Juss. из природных популяций лесостепной зоны Западной Сибири.

\section{Экспериментальная часть}

Материалом для исследования служили образцы растений земляники лесной, лабазника обыкновенного, кровохлебки лекарственной, манжетки обыкновенной, репейничка волосистого, шиповника майского, собранные в окрестностях г. Новосибирска в 2009 и 2010 гг. Сырье сушили до воздушно-сухого состояния, упаковывали в бумажные пакеты и хранили в прохладном месте. Изучали отдельные органы растений (листья, цветки, корни).

Для количественного определения флавоноидов применяли спектрофотометрический метод В.В. Беликова, в котором использована реакция комплексообразования флавоноидов с хлоридом алюминия [3].

\section{Обсуждение результатов}

На содержание флавоноидов проанализировано по 16 образцов листьев и корней и 14 образцов цветков шести видов растений семейства розоцветные. Результаты исследования представлены в таблице. Мак-

Шалдаева Татьяна Михайловна - научный сотрудник лаборатории фитохимии, кандидат биологических наук, e-mail: tshaldaeva@yandex.ru симальным содержанием флавоноидов в листьях и цветках характеризуются растения манжетки обыкновенной $(5,0$ и $3,8 \%$ соответственно) и лабазника обыкновенного $(4,8$ и $8,3 \%)$. 
Содержание флавоноидов в органах растений некоторых видов семейства Rosaceae (\% от массы воздушносухого сырья)

\begin{tabular}{|c|c|c|c|}
\hline \multirow{2}{*}{ Название растений, место и дата сбора образцов } & \multicolumn{3}{|c|}{ Содержание флавоноидов (\%) } \\
\hline & листья & цветки & корни \\
\hline Fragaria vesca L. земляника лесная, & 3,9 & $-*$ & 0,3 \\
\hline г. Новосибирск, окр. ЦСБС, опушка леса, 15.09.2009. & & & \\
\hline Там же, вдоль лесной дороги, 4.07.2009. & 2,7 & 1,6 & 0,2 \\
\hline Там же, возле березового колка, 21.07.2010. & 1,3 & 1,0 & 0,3 \\
\hline $\begin{array}{l}\text { г. Новосибирск, окр. пос. Матвеевка, опушка леса, } \\
\text { 27.06.2009. }\end{array}$ & 1,2 & 2,0 & 0,1 \\
\hline $\begin{array}{l}\text { Новосибирская область, Тогучинский р-н, окр. с. Златоуст, } \\
\text { опушка леса, 20.06.2009. }\end{array}$ & 1,1 & 1,6 & 0,2 \\
\hline $\begin{array}{l}\text { Filipendula vulgaris Moench., лабазник обыкновенный, } \\
\text { г. Новосибирск, окр. пос. Матвеевка, берег реки, 20.07.2009. }\end{array}$ & 3,2 & 3,1 & 1,1 \\
\hline $\begin{array}{l}\text { Новосибирский р-н, с. Барышево, поляна возле леса, } \\
\text { 21.07.2010. }\end{array}$ & 4,8 & 8,3 & 1,0 \\
\hline $\begin{array}{l}\text { Новосибирская обл., Искитимский р-н, окр. с. Бурмисто- } \\
\text { рово, возле березового колка, 7.07.2009. }\end{array}$ & 4,4 & 6,2 & 0,9 \\
\hline $\begin{array}{l}\text { Sanguisorba officinalis L., кровохлебка лекарственная, } \\
\text { г. Новосибирск, окр. ЦСБС, опушка леса, 15.09.2009. }\end{array}$ & 1,6 & 3,6 & 2,7 \\
\hline $\begin{array}{l}\text { Alchemilla vulgaris L.s.1., манжетка обыкновенная, } \\
\text { г. Новосибирск, окр. пос. Матвеевка, 27.06.2009. }\end{array}$ & 5,0 & 3,8 & 4,8 \\
\hline окр. ЦСБС, бывший экспозиционный участок, 25.09.2009. & 4,5 & - & 4,9 \\
\hline Там же, вдоль лесной дороги, 15.09.2009. & 3,0 & 2,0 & 4,1 \\
\hline $\begin{array}{l}\text { Agrimonia pilosa Ledeb., pепейничек волосистый, } \\
\text { г. Новосибирск, окр. ЦСБС, вдоль лесной дороги, 15.08.2009. }\end{array}$ & 1,4 & 1,7 & 1,1 \\
\hline Там же, опушка леса, 21.07.2010. & 1,1 & 0,4 & 0,8 \\
\hline $\begin{array}{l}\text { Rosa majalis Herrm., шиповник майский, г. Новосибирск, } \\
\text { окр. пос. Матвеевка, 21.06.2009. }\end{array}$ & 3,0 & 1,8 & 0,6 \\
\hline окр. ЦСБС, опушка леса, 21.07.2010. & 2,1 & 2,3 & 0,3 \\
\hline
\end{tabular}
Примечание. *- отсутствие материала.

У земляники лесной содержание флавоноидов варьировало в зависимости от места сбора: в листьях от 1,1 до $3,9 \%$, в цветках - от 1,0 до $2,0 \%$, и в корнях - от 0,1 до $0,3 \%$. По количеству флавоноидов можно выделить популяции земляники из окр. Академгородка, собранные на опушке леса и вдоль лесной дороги. Содержание флавоноидов у лабазника обыкновенного варьировало от 3,2 до 4,8\% в листьях, от 3,1 до 8,3\% - в цветках, и от 0,9 до 1,1\% - корнях. Выделяется популяция из окрестностей с. Барышева (поляна возле леса). Количество флавоноидов в листьях манжетки обыкновенной изменялось от 3,0 до 5,0\%, в цветках от 2,0 до 3,8\%. Корни манжетки отличались высоким содержанием флавоноидов - от 4,1 до 4,8\%, выделяется образец из окрестностей пос. Матвеевки. У кровохлебки лекарственной количество флавоноидов в листьях и цветках было 1,6 и 3,6\% соответственно.

Содержание флавоноидов у репейничка волосистого находилось в пределах 1,1-1,4\% (в листьях) и 0,4-1,7\% (в цветках), а у шиповника майского 2,1-3,0\% (в листьях) и 1,8-2,3\% (в цветках). В подземных органах содержание флавоноидов изменялось у репейничка волосистого от 0,8 до $1,0 \%$, у шиповника майского - от 0,3 до $0,6 \%$.

\section{Заключение}

Результаты проведенного исследования свидетельствуют о том, что значительное содержание флавоноидов в растениях изученных видов позволяет рассматривать их в качестве источников средств лечебного и профилактического назначения. Растения с содержанием флавоноидов 2,0\% и более могут быть использованы в качестве флавоноидоносного сырья.

\section{Список литературы}

1. Минаева В.Г. Флавоноиды в онтогенезе растений и их практическое использование. Новосибирск, 1978. 256 с.

2. Киселева А.В., Волхонская Т.А., Киселев В.С. Биологически активные вещества лекарственных растений Южной Сибири. Новосибирск, 1991. 91 с.

3. Беликов В.В., Шрайбер М.С. Методы анализа флавоноидных соединений // Фармация. 1970. Т. 19. №1. С. 66-72. 
Shaldaeva T.M. CONTENT OF FLAVONOIDS IN SOME REPRESENTATIVES OF FAMILY ROSACEAE JUSS. FROM NATURAL POPULATIONS OF A FOREST-STEPPE ZONE OF WESTERN SIBERIA

Central Siberian Botanical Garden SB RAS, st. Zolotodolinskaia, 101, Novosibirsk, 630090 (Russia), e-mail: tshaldaeva@yandex.ru

Last years more and more attention it is given to search of new herbs containing considerable percent of flavonoids and working out of preparations from the vegetative raw materials used in national medicine. The maintenance of flavonoids in vegetative raw materials is the major indicator of its biological value. The purpose of the present work - maintenance research of flavonoids in an elevated and underground part of plants of family Rosaceae. It is analysed on 16 samples of leaves and roots and 14 samples of flowers of the wild-growing plants representing to populations from a forest-steppe zone of Western Siberia. It is established that the maximum maintenance of flavonoids in leaves and flowers characterizes plants Alchemilla vulgaris (5,0 and 4,8\%) and Filipendula vulgaris (3,8 and 8,3\%), accordingly

Keywords: Rosaceae Juss, flavonoids.

\section{References}

1. Minaeva V.G. Flavonoidy v ontogeneze rastenii i ikh prakticheskoe ispol'zovanie. [Flavonoids in the ontogeny of plants and their practical use]. Novosibirsk, 1978, 256 p. (in Russ.).

2. Kiseleva A.V., Volkhonskaia T.A., Kiselev V.S. Biologicheski aktivnye veshchestva lekarstvennykh rastenii Iuzhnoi Sibiri. [Biologically active substances of medicinal plants of South Siberia]. Novosibirsk, 1991, 91 p. (in Russ.).

3. Belikov V.V., Shraiber M.S. Farmatsiia, 1970, vol. 19, no. 1, pp. 66-72. (in Russ.).

Received February 12, 2012 